\title{
The South African Banking Director Network: An Investigation Into Interlocking Directorships Using Social Network Analysis (SNA)
}

Burgert A. Senekal, University of the Free State, South Africa Karlien Stemmet, University of the Free State, South Africa

\begin{abstract}
The theory of complex systems has gained significant ground in recent years, and with it, complex network theory has become an essential approach to complex systems. This study follows international trends in examining the interlocking South African bank director network using social network analysis (SNA), which is shown to be a highly connected social network that has ties to many South African industries, including healthcare, mining, and education. The most highly connected directors and companies are identified, along with those that are most central to the network, and those that serve important bridging functions in facilitating network coherence. As this study is exploratory, numerous suggestions are also made for further research.
\end{abstract}

Keywords: Social Network Analysis (SNA); Complex Social Systems; Complex Networks; Bank Directors; South African Banking

\section{INTRODUCTION}

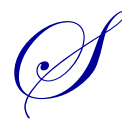

ince the mid-1990s, the theory of complex systems has gained significant ground in a variety of academic disciplines, including in economics. Most of the social environment can be described as a complex system, where millions of actors interact to produce complex emergent properties, non-linear interactions and adaptability, as Kwapień and Drożdż (2012, p. 118) define a complex system, "a complex system is a system built from a large number of nonlinearly interacting constituents, which exhibits collective behaviour and, due to an exchange of energy or information with the environment, can easily modify its internal structure and patterns of activity." International trade is no different; indeed, Kwapień and Drożdż (2012, p. 118) specifically name financial markets as an example of a complex system.

Along with complex systems theory, the theory of complex networks has recently gained ground in a variety of disciplines, starting with the seminal studies by Watts and Strogatz (1998) and Barabási and Albert (1999) (although the theory itself can be traced back to Leonard Euler's Königsberg bridge puzzle of 1736, see Amaral and Ottino, 2004, p. 151). Complex network theory is an approach to complex systems, and uses network theory's ability to represent a network visually, along with network theory's variety of mathematical formulae, to calculate the roles entities play in a network. Barabási (2009, p. 413) writes:

Today the understanding of networks is a common goal of an unprecedented array of traditional disciplines: Cell biologists use networks to make sense of signal transduction cascades and metabolism, to name a few applications in this area; computer scientists are mapping the Internet and the WWW; epidemiologists follow transmission networks through which viruses spread; and brain researchers are after the connectome, a neural-level connectivity map of the brain. Although many fads have come and gone in complexity, one thing is increasingly clear: Interconnectivity is so fundamental to the behaviour of complex systems that networks are here to stay. 
Network theory has proved an important and essential approach to complex systems in fields as diverse as epidemiology, biology, security studies, and communication science (Luke \& Stamatakis, 2012, p. 362). Economics has also utilised network theory: Smith and White (1992, p. 861) already wrote that Snyder and Kick (1979) and Steiber (1979) were "the first explicit attempts to use the network approach to examine the world-system." Since these publications, global economic systems have been approached as networks in numerous studies (see Nemeth \& Smith, 1985; Smith \& White, 1992, p. 857; Jackson, 2007; De Benedictis \& Tajoli, 2008; Flandreau \& Jobst, 2005, 2009). Fricke, Finger, and Lux (2013, p. 2) write, "[I]nvestigations of complex systems in terms of their network properties gain more and more attention in economics following the lead of other disciplines in which network analyses have already a long tradition."

A classic application of network theory in the field of economics is the study of interlocking directorships (see e.g., Heemskerk, 2013; Comet \& Pizarro, 2011; Conyon \& Muldoon, 2006; Robins \& Alexander, 2004; Davis, Yoo, \& Baker, 2003; Alexander, 2003; Mintz \& Schwartz, 1985; Useem, 1984; Mizruchi, 1982; Levine, 1977). By approaching the network of directors as a social network, insight is gained into how ideas spread within an economy. As Davis, Yoo, and Baker (2003, p. 305) write:

...while the origins of ties among firms and directors may be primarily social rather than strategic, dozens of studies since the late 1980s have documented the influence of shared directorships on choices about corporate strategy and structure, from the ideological tone of political activism to basic choices about organization design.

At the heart of a country's financial industry lies the banking industry; Davis, Yoo, and Baker (2003, p. 302) call commercial banks "the traditional centre of the interlock network" (although in the US economy, banks lost their position of centrality by the mid-1990s, Davis, Yoo, and Baker, 2003, p. 309). Banks often recruit wellconnected CEOs (Davis, Yoo, \& Baker, 2003, p. 303), which allows them to monitor important economic sectors closely, and it therefore comes as no surprise that the banking industry in particular has been studied as a network (Davis \& Mizruchi, 1999). Approaching the banking industry as a network therefore provides a view of the financial core of a country's economy in terms of interlocking directorships, and those companies that share this core can be seen as belonging to key industries in an economy.

The current study examines the current interlocking directorships associated with the banking industry in South Africa (as of 1 October 2013). Using the list of South African banks provided in the South African Reserve Bank's Department of Banking Supervision (2012), data on currently serving company directors was gathered using the detailed company overviews provided through Bloomberg's BusinessWeek (http://www.businessweek.com/), and it was recorded which directors are affiliated with which other directors, apart from those in their own company. Because a director does not necessarily serve on the boards of all subsidiary companies of a parent company, the boards of directors of subsidiary companies was also distinguished. The companies involved were also recorded, meaning that person $\mathrm{A}$ is a director of bank $\mathrm{B}$, but also sits on the board of company $\mathrm{C}$ with directors $\mathrm{D}, \mathrm{E}$, and $\mathrm{F}$, who in turn also serve on the boards of companies G, H, and I. The resulting network is what Watts (2004, p. 248) calls a bipartite network, which consists of two types of entities: people and companies (see also Koskinen \& Edling 2012, p. 309; Conyon \& Muldoon, 2006, p. 1326). In total, this network consists of 3,204 entities (people and companies) and 10,157 relationships, and these relationships were plotted using Sentinel Visualizer, a specialised Social Network Analysis program developed for the US intelligence community. Although the data is surely not complete, it is a comprehensive database of interlocking directorships centred on the South African banking industry. In this article, the emphasis falls on what Kwapień and Drożdż (2012, p. 210) call "Microscopic topological properties of a network," namely node degrees, betweenness, and the existence of particular edges, rather than on macroscopic network properties such as average path length, scale-free link distributions and the like, because macroscopic network properties have already been thoroughly documented in the study of company director networks (see e.g., Nicholson, Alexander, \& Kiel, 2004; Conyon \& Muldoon, 2006).

\section{OVERVIEW OF NETWORK THEORY}

Because network theory is an unfamiliar theoretical approach in South Africa, the following section provides an overview of the major principles involved. 
Virtually any system can be studied as a network, which consists of entities (also called actors, nodes, or vertices), and their relationships (also called ties, links, or edges) (Brandes, Freeman, \& Wagner, 2013, p. 805; Onel, Zeid, \& Kamarthi, 2011, p. 120; Newman, 2001, p. 404; Newman, 2003, p. 168; Dos Santos et al., 2012, p. 240). The interdisciplinary roots of network theory, which are found mainly in mathematical graph theory, sociology, and anthropology, result in a multitude of terms associated with the same phenomena, but the core of the theory remains the same regardless of the application: the total network is capable of a greater functionality than the sum of individual parts (emergence). In network theory, the emphasis falls on the relationships between entities rather than on entities' individual characteristics (Serrat, 2010, p. 2).

Numerous studies - particularly by the physics community - have found further universal properties of complex networks. Newman (2003) distinguishes between four types of complex networks: biological networks, technological networks, information networks, and social networks. Biological networks include ecosystems, protein networks, neurological networks, metabolic processes, and food webs, while technological networks include the Internet, transport networks, and power grids. Information networks include the World Wide Web and citation networks in academic fields, while social networks include everything from film actor networks, terrorist networks, and family and friendship networks, to interlocking director networks of international companies and organisations. All of these exhibit similar characteristics, including amongst others small-worldedness, the existence of highly connected entities, scale-free link distributions, robustness, clustering, and assortativity (Amaral \& Ottino, 2004, p. 151; Buchanan, 2003, p. 15), as Barabási (2009, p. 412) writes:

... probably the most surprising discovery of modern network theory is the universality of the network topology: Many real networks, from the cell to the Internet, independent of their age, function, and scope, converge to similar architectures. It is this universality that allowed researchers from different disciplines to embrace network theory as a common paradigm.

Small-worldedness refers to the phenomenon that, on average, every entity in a network is connected to every other entity via a relatively short path, as noted by Watts and Strogatz (1998). Strogatz (2004[2003], p. 232) writes, "the "small-world' phenomenon is much more than a curiosity of human social life: It's a unifying feature of diverse networks found in nature and technology" (see also Watts 2004[2003], p. 100). In terms of company directors, the research done by Conyon and Muldoon (2006, p. 1337) on directorships in the US, UK, and Germany, as well as by Nicholson, Alexander, and Kiel (2004) on directorships in the US and Australia, support Watts and Strogatz's prediction that small-worldedness is a near-universal characteristic of complex networks: both found short average path lengths between entities in company director networks.

Scale-free (power law) link distributions were first identified by Barabási and Albert (1999), and denotes that there are few highly connected entities in a network, while the majority of entities are poorly connected (Watts, 2004, p. 248; Buchanan, 2003, pp. 84-85). Scale-free link distributions are similar to Pareto's Law - the familiar $80 / 20$ division of wealth in society, where the majority of the population each hold little of a country's total wealth, while the majority of a country's wealth can be found in the hands of a select few. In terms of network topology, the power law predicts that link distributions will be similarly scaled, with the vast majority of entities having few ties in the network, while a few entities will be extremely well connected. This trend has also been compared with the highly similar Matthew Effect, Zipf's Law, and Lotka's Law of scientific productivity (Newman, 2005, p. 340), and has been found in diverse networks; as Kwapień and Drożdż (2012, p. 207) write, the phenomenon has been observed in "actor co-appearances in movies, scientific paper citations, Internet physical structure, air traffic and airport networks, Internet social networks, sexual contact networks, epidemic networks, metabolic networks, genecoexpression networks, and many other systems" (see also Newman, 2005, p. 325, Barabási, 2009, p. 412; Buchanan, 2003, p. 83; Clauset, Shalizi, \& Newman, 2009). As can be expected, the same link distribution can be observed in interlocking directorship networks, as Conyon and Muldoon (2006, p. 1335) write:

The average size of a US board is about 10 members and each director, on average, has 1.63 directorships (including the directorship at his or her main company). An individual occupying only one board position is a oneboard director. Analogously, a person with two directorships is a two-board director. In the US, the overwhelming majority of directors (about 80\%) have only one directorship. About 13\% hold precisely two positions, implying that a very small fraction of directors (7\%) hold more than two director posts. 
This characteristic of complex networks results in network robustness: when the majority of entities are not well connected, complex networks were found to be highly robust against random failures, because it is unlikely that the few well connected entities will fail when surrounded by a large number of less well connected entities. However, complex networks were found to be highly susceptible to cascading failures when these highly connected entities are removed from the network (Buchanan, 2003, p. 131). The scale-free link distribution is thus a proverbial double-edged sword in terms of network robustness: complex networks are robust, but only against random failure (Watts, 2004[2003], pp. 191-2; Haldane, 2009, p. 11). Kwapień and Drożdż (2012, p. 126) refer to this characteristic of complex systems as Highly Optimized Tolerance (HOT), where "A complex system, as understood by HOT, is very flexible to both the internal perturbations and errors and the unfavourable external factors." Simultaneously, "highly optimized, tolerant systems are significantly vulnerable to very rare, unusual events (e.g., cascading failures)."

Another topological feature of complex networks is clustering, which refers to the tendency of entities to form clusters or subgroups, where entities within the cluster are more highly connected than they are with entities outside the cluster (Zhu, Watts, \& Chen, 2010, p. 152). In terms of network structure, clustering often leads to the formation of triangles, where; e.g., entities B and C, who are connected to entity A, are also connected to each other. More formally, clustering can be defined as "the propensity for vertex pairs (e.g., boards) to be connected if they share a mutual neighbour" (Conyon \& Muldoon, 2006, p. 1322, see also Newman, 2003, p. 183).

Assortativity refers to the tendency of similar entities to form connections. In terms of social networks, it has been found in numerous studies that people tend to associate according to race, income level, and/or age (Newman, 2003, p. 191). A specific form of assortativity is degree correlation, where the best-connected entities tend to form ties to other highly connected entities (Watts, 2004, pp. 258-259). This is one of few areas where social networks differ from other types of networks: while social networks are assortative, other types of networks were found to be disassortative (Newman, 2003, p. 193). Again, assortativity was found in director networks: Conyon and Muldoon (2006, p. 1342) for instance found a positive degree correlation between directors, and write, "[D]irectors who sit on many boards appear to do so in the company of others who also sit on many boards."

While it is not the objective of this article to test the South African banking industry director network against the above topological features of complex networks, note that clusters and highly-connected entities (forming star structures) can be identified visually through a graph:

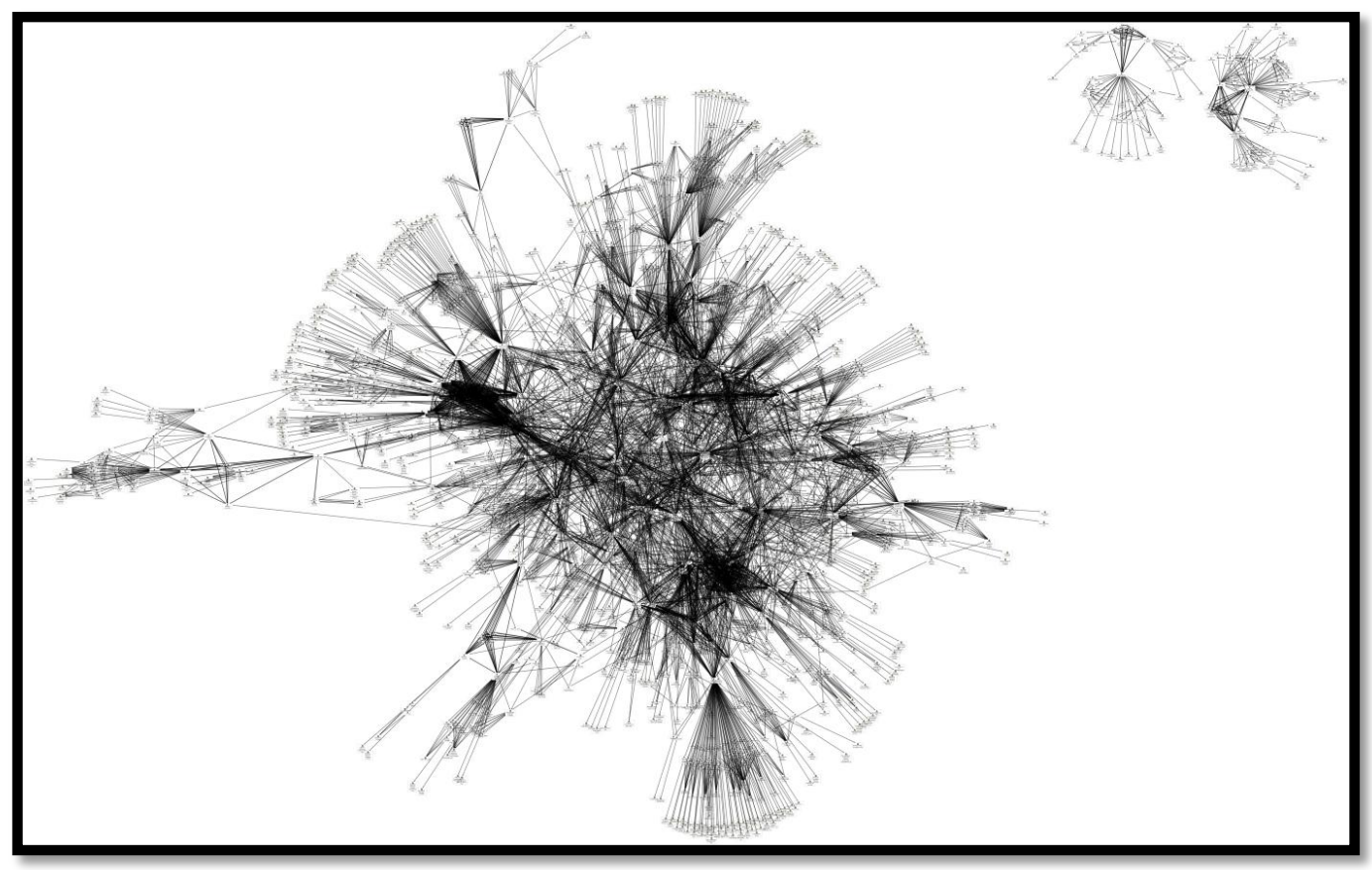

Figure 1: The Total Network of Directors in the South African Banking Industry 
Here it can be seen that although the industry is highly connected, two clusters are unconnected to the rest of the network (at the top right of the graph). These are Habas Investments (1960) Ltd. and Albaraka Turk Katilim Bankas, who are also not connected to each other. The implication is that these two banks are not connected to the South African economy via the director network, and their separation influences an analysis of the network directly, as the following discussion shows.

\section{CENTRALITY MEASURES}

While the previous section discussed some macro level characteristics of complex networks with specific reference to interlocking director networks, at the micro level, entities' roles can be studied with a variety of measures. In order to calculate the roles entities play in a network, the most widely used centrality measures are those developed by Freeman (1979), namely degree centrality, closeness centrality, and betweenness centrality, as discussed in the following paragraphs. However, because closeness centrality cannot be calculated when parts of a network are unconnected, as is the case here since two banks are not connected to the rest of the industry, these two banks were removed from the network to facilitate the following discussion.

Degree centrality calculates the number of ties an entity has with its direct neighbours (Donges et al., 2009, p. 158; Barnes \& Ritter, 2001, p. 207), and a high degree centrality simply means that such an entity has more direct ties to his neighbours than other entities. Degree centrality is a measure of activity (Freeman, 1979, p. 238); in the banking director network, the people with the highest degree centralities are those with the most connections to other entities, both to people and companies. The formula for calculating degree centrality for node $i$ is the following (Prell, 2012, p. 97):

$\mathrm{C}_{\mathrm{D}}(i)=\sum_{j=1}^{\mathrm{n}} x_{i j}=\sum_{i=1}^{\mathrm{n}} x_{i j}$

Where,

$x_{i j}=$ the value of the tie from actor $i$ to actor $j$ (the value being either 0 or 1), and thus it is the sum of all ties $n=$ the number of nodes in the network

Note however that, in contrast to the assertion by Mahdi et al. (2012, p. 278), degree centrality is not necessarily a measure of influence, because it is also important to note where an entity's connections lead (Prell, 2012, p. 97). An entity could have a large number of connections to lower-level entities, which are less important in terms of the overall structure of the network than connections to entities with a high betweenness centrality.

Betweenness centrality measures to what extent an entity lies on the shortest path between other entities in a network, and often whether an entity lies on the only path between other entities. An entity with a high betweenness centrality is therefore in a favourable position to control the flow of information in a network. As Freeman (1979, p. 221) originally noted, betweenness centrality identifies "a point that falls on the communication paths between other points [which] exhibits a potential for control of their communication." Furthermore, entities with a high betweenness centrality contribute to network coherence; without them, a network easily disintegrates into unconnected clusters (Dos Santos et al., 2012, p. 240; Hafner Burton, Kahler, \& Montgomery, 2009, p. 564), and therefore entities with a high betweenness centrality contribute most to facilitating the flow of information in a network. Betweenness centrality is calculated with the following formula (Prell, 2012, p. 105):

$C_{B}(k)=\sum \partial_{i k j} / \partial_{i j}, i \neq j \neq k$

$\partial_{i k j}=$ the number of geodesics linking actors $i$ and $j$ that pass through node $k$;

$\partial_{i j}=$ the number of geodesics linking nodes $i$ and $j$, and thus the betweenness calculation is for node $k$.

In terms of the interlocking director network, Davis, Yoo, and Baker (2003, p. 319) refer to "linchpin directors" who serve as bridges between companies, and use the betweenness centrality measure to identify these linchpins. 
Closeness centrality refers to how close an entity is, in terms of connections, to all other entities in a network. Entities with a high closeness centrality have a short path to most other entities in a network (Butts, 2008, p. 23), and are therefore central role players. Closeness centrality is calculated with the following formula (Prell, 2012, p. 108):

$C_{C}(i)=\sum d_{i j}$ where $d_{i j}=$ the distance connecting actor $i$ to actor $j$.

The following table gives the degree-, betweenness-, and closeness centrality scores of the highest-scoring 40 company directors in this network:

Table 1: The Degree, Betweenness, and Closeness Centrality Scores of the Highest-Scoring 40 Company Directors

\begin{tabular}{|c|c|c|c|c|c|}
\hline Entity Name & 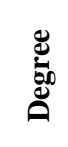 & Entity Name & 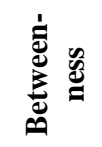 & Entity Name & 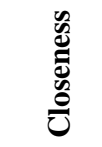 \\
\hline 1. Jan Jonathan Durand & 151 & Steven B. Epstein & 1.0000 & Nigel George Payne & 1.0000 \\
\hline 2. $\quad$ Cheryl Ann Carolus & 141 & Jan Jonathan Durand & 0.8469 & Benedict James van der Ross & 0.9861 \\
\hline 3. $\quad$ Steven B. Epstein & 130 & Cheryl Ann Carolus & 0.8265 & Jan Jonathan Durand & 0.9851 \\
\hline 4. Stephen Koseff & 126 & $\begin{array}{l}\text { Nomavuso Patience } \\
\text { Mnxasana }\end{array}$ & 0.8201 & Paul Cambo Baloyi & 0.9847 \\
\hline $\begin{array}{ll}\text { 5. Nomavuso Patience } \\
\text { Mnxasana }\end{array}$ & 120 & Fani Titi & 0.8189 & Stephen Koseff & 0.9782 \\
\hline $\begin{array}{ll}6 . & \text { Benedict James van der } \\
& \text { Ross }\end{array}$ & 116 & Stephen Koseff & 0.7227 & $\begin{array}{l}\text { Douglas Denoon Balharrie } \\
\text { Band }\end{array}$ & 0.9762 \\
\hline 7. Myles J. D. Ruck & 99 & $\begin{array}{l}\text { Benedict James van der } \\
\text { Ross }\end{array}$ & 0.7065 & Fani Titi & 0.9611 \\
\hline 8. Hugh Sidney Herman & 95 & $\begin{array}{l}\text { Douglas Denoon Balharrie } \\
\text { Band }\end{array}$ & 0.6071 & Myles J. D. Ruck & 0.9521 \\
\hline 9. Nigel George Payne & 95 & Grant Glenn Gelink & 0.5736 & Wendy Elizabeth Lucas-Bull & 0.9492 \\
\hline 10. Fani Titi & 93 & Nigel George Payne & 0.5724 & Nomavuso Patience Mnxasana & 0.9484 \\
\hline 11. Grant Glenn Gelink & 92 & Myles J. D. Ruck & 0.5165 & William Rodger Jardine & 0.9360 \\
\hline $\begin{array}{l}\text { 12. Peter Mangalani } \\
\text { Malungani }\end{array}$ & 91 & William Rodger Jardine & 0.4935 & Grant Glenn Gelink & 0.9293 \\
\hline 13. William Rodger Jardine & 91 & Sandile D. M. Zungu & 0.4739 & Koosum Parsotam Kalyan & 0.9277 \\
\hline 14. Bernard Kantor & 90 & Koosum Parsotam Kalyan & 0.4662 & Cheryl Ann Carolus & 0.9269 \\
\hline 15. Sandile D. M. Zungu & 88 & Robert Haldane Smith & 0.4476 & $\begin{array}{l}\text { Nolulamo Nobambiswano } \\
\text { Gwagwa }\end{array}$ & 0.9179 \\
\hline $\begin{array}{l}\text { 16. Kgomotso Ditsebe } \\
\text { Moroka }\end{array}$ & 85 & Paul Cambo Baloyi & 0.4021 & Hugh Sidney Herman & 0.9160 \\
\hline 17. Haruko Fukuda & 84 & $\begin{array}{l}\text { Wendy Elizabeth Lucas- } \\
\text { Bull }\end{array}$ & 0.3746 & Dhanasagree Naidoo & 0.9113 \\
\hline 18. Leon Crouse & 84 & Hugh Sidney Herman & 0.3674 & $\begin{array}{l}\text { Thoko Martha Mokgosi- } \\
\text { Mwantembe }\end{array}$ & 0.9056 \\
\hline 19. Mary Sina Bomela & 82 & Gloria Tomatoe Serobe & 0.3276 & Peter Mangalani Malungani & 0.9021 \\
\hline 20. Paul Cambo Baloyi & 82 & Kgomotso Ditsebe Moroka & 0.3186 & Gloria Tomatoe Serobe & 0.9003 \\
\hline 21. Robert Haldane Smith & 81 & Mary Sina Bomela & 0.3011 & Sandile D. M. Zungu & 0.8981 \\
\hline 22. Yolanda Zoleka Cuba & 81 & $\begin{array}{l}\text { Thoko Martha Mokgosi- } \\
\text { Mwantembe }\end{array}$ & 0.2990 & Leon Crouse & 0.8981 \\
\hline $\begin{array}{l}\text { 23. Douglas Denoon } \\
\text { Balharrie Band }\end{array}$ & 78 & Dhanasagree Naidoo & 0.2915 & Peter Bambatha Matlare & 0.8966 \\
\hline 24. Gloria Tomatoe Serobe & 78 & Yolanda Zoleka Cuba & 0.2900 & Paul Kenneth Harris & 0.8943 \\
\hline 25. Hendrik Jacobus du Toit & 78 & Trevor Stewart Munday & 0.2683 & Steven B. Epstein & 0.8869 \\
\hline $\begin{array}{ll}\text { 26. } & \text { Nolulamo } \\
\text { Nobambiswano Gwagwa }\end{array}$ & 78 & Louis Leon Von Zeuner & 0.2535 & Bernard Kantor & 0.8820 \\
\hline $\begin{array}{l}\text { 27. Peregrine Kenneth } \\
\text { Oughton Crosthwaite }\end{array}$ & 78 & Peter Bambatha Matlare & 0.2518 & Amanda Tandiwe Nzimande & 0.8772 \\
\hline
\end{tabular}


Table 1 cont.

\begin{tabular}{|c|c|c|c|c|c|}
\hline $\begin{array}{l}\text { 28. Peter Richard Suter } \\
\text { Thomas }\end{array}$ & 78 & $\begin{array}{l}\text { Nolulamo Nobambiswano } \\
\text { Gwagwa }\end{array}$ & 0.2361 & Trevor Stewart Munday & 0.8757 \\
\hline 29. Trevor Stewart Munday & 78 & Peter Mangalani Malungani & 0.2323 & Bradley Fried & 0.8714 \\
\hline $\begin{array}{l}\text { 30. Wendy Elizabeth Lucas- } \\
\text { Bull }\end{array}$ & 78 & Haruko Fukuda & 0.2219 & Louis Leon Von Zeuner & 0.8695 \\
\hline 31. Bradley Fried & 77 & Bradley Fried & 0.1956 & Haruko Fukuda & 0.8666 \\
\hline $\begin{array}{ll}\text { 32. } & \begin{array}{l}\text { Koosum Parsotam } \\
\text { Kalyan }\end{array}\end{array}$ & 76 & $\begin{array}{l}\text { Peregrine Kenneth Oughton } \\
\text { Crosthwaite }\end{array}$ & 0.1645 & Glynn R. Burger & 0.8662 \\
\hline $\begin{array}{l}\text { 33. Thoko Martha Mokgosi- } \\
\text { Mwantembe }\end{array}$ & 75 & Leon Crouse & 0.1448 & Robert Haldane Smith & 0.8660 \\
\hline $\begin{array}{l}\text { 34. Amanda Tandiwe } \\
\text { Nzimande }\end{array}$ & 73 & Hendrik Jacobus du Toit & 0.1412 & $\begin{array}{l}\text { Peregrine Kenneth Oughton } \\
\text { Crosthwaite }\end{array}$ & 0.8657 \\
\hline 35. Dhanasagree Naidoo & 73 & $\begin{array}{l}\text { Amanda Tandiwe } \\
\text { Nzimande }\end{array}$ & 0.1186 & Hendrik Jacobus du Toit & 0.8657 \\
\hline 36. Louis Leon Von Zeuner & 73 & Bernard Kantor & 0.0901 & Mary Sina Bomela & 0.8656 \\
\hline 37. Paul Kenneth Harris & 73 & $\begin{array}{l}\text { Peter Richard Suter } \\
\text { Thomas }\end{array}$ & 0.0695 & Peter Richard Suter Thomas & 0.8656 \\
\hline 38. Peter Bambatha Matlare & 73 & Lauritz Lanser Dippenaar & 0.0577 & Kgomotso Ditsebe Moroka & 0.8645 \\
\hline 39. Glynn R. Burger & 72 & Paul Kenneth Harris & 0.0553 & Yolanda Zoleka Cuba & 0.8645 \\
\hline 40. Lauritz Lanser Dippenaar & 69 & Glynn R. Burger & 0.0281 & Lauritz Lanser Dippenaar & 0.8636 \\
\hline
\end{tabular}

This means that Jan Jonathan Durand has the highest number of direct connections in this network, Cheryl Ann Carolus the second highest number, etcetera. Note that degree centrality in this instance refers to directors' connections to both other directors and companies. As discussed previously, degree centrality is a measure of activity, and thus these are the directors that are most active in the South African bank industry in terms of the interlocking director network. Jan Jonathan Durand is for instance linked directly to a large number of directors, to a total of 145 connections to directors (his remaining six connections are to companies).

The betweenness centrality scores indicate to what extent entities serve as linchpins by connecting companies, providing coherence to the industry. Again, Durand scores high, along with Steven B. Epstein, Cheryl Ann Carolus, and Nomavuso Patience Mnxasana.

The interlocking director network of course serves to link companies together, providing the opportunity for the banking industry to monitor various sectors of the economy to mitigate lending risks. The following table provides the degree-, betweenness-, and closeness centralities of the 40 highest-scoring companies in this network:

Table 2: The Degree, Betweenness, and Closeness Centralities of the 40 Highest-Scoring Companies

\begin{tabular}{|c|c|c|c|c|c|}
\hline Entity & 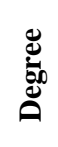 & Entity & 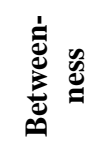 & Entity & 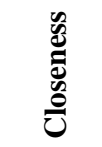 \\
\hline 1. Investec Limited & 45 & Tiger Brands Limited & 0.0774 & Bidvest Group Ltd & 0.9319 \\
\hline $\begin{array}{l}\text { 2. International Crisis Group } \\
\text { (The) }\end{array}$ & 43 & Deenadayalen Konar & 0.0637 & MTN Group Limited & 0.8800 \\
\hline 3. Investec plc & 36 & CIDA Empowerment Fund & 0.0455 & Investec Limited & 0.8633 \\
\hline $\begin{array}{ll}\text { 4. Standard International } \\
\text { Holdings SA }\end{array}$ & 34 & Santam Ltd. & 0.0446 & Investec plc & 0.8624 \\
\hline 5. Standard Chartered PLC & 32 & Barclays Africa Group Limited & 0.0425 & FirstRand Limited & 0.8584 \\
\hline 6. Investec Bank Plc & 29 & MTN Group Limited & 0.0302 & $\begin{array}{l}\text { Standard Bank Group } \\
\text { Limited }\end{array}$ & 0.8479 \\
\hline 7. FirstRand Limited & 28 & $\begin{array}{l}\text { Steinhoff International } \\
\text { Holdings Ltd. }\end{array}$ & 0.0208 & $\begin{array}{l}\text { Anglo American Platinum } \\
\text { Limited }\end{array}$ & 0.8447 \\
\hline 8. Radius Ventures, LLC & 27 & Bidvest Group Ltd & 0.0203 & $\begin{array}{l}\text { The Standard Bank of South } \\
\text { Africa Limited }\end{array}$ & 0.8369 \\
\hline
\end{tabular}


Table 2 cont.

\begin{tabular}{|c|c|c|c|c|c|}
\hline $\begin{array}{ll}\text { 9. } & \text { Standard Bank Group } \\
& \text { Limited }\end{array}$ & 27 & $\begin{array}{l}\text { Kagiso Tiso Holdings } \\
\text { Proprietary Limited }\end{array}$ & 0.0198 & JSE Limited & 0.8355 \\
\hline 10. Bidvest Group Ltd & 23 & FirstRand Limited & 0.0194 & Investec Bank Plc & 0.8354 \\
\hline $\begin{array}{l}\text { 11. Steinhoff International } \\
\text { Holdings Ltd. }\end{array}$ & 23 & $\begin{array}{l}\text { Pan-African Capital Holdings } \\
\text { (PTY) Ltd. }\end{array}$ & 0.0173 & $\begin{array}{l}\text { Barclays Africa Group } \\
\text { Limited }\end{array}$ & 0.8349 \\
\hline 12. Tiger Brands Limited & 23 & Nedbank, Ltd. & 0.0161 & Deenadayalen Konar & 0.8311 \\
\hline $\begin{array}{l}\text { 13. Compagnie Financiere } \\
\text { Richemont SA }\end{array}$ & 21 & Transnet SOC Limited & 0.0157 & Mr Price Group Limited & 0.8268 \\
\hline 14. Aveng Limited & 20 & $\begin{array}{l}\text { Compagnie Financiere } \\
\text { Richemont SA }\end{array}$ & 0.0153 & Remgro Limited & 0.8253 \\
\hline $\begin{array}{l}\text { 15. DigiCore Holdings } \\
\text { Limited }\end{array}$ & 20 & ConvergeNet Holdings Limited & 0.0144 & Pick n Pay Stores Ltd. & 0.8241 \\
\hline 16. Investec Bank Limited & 20 & Aveng Limited & 0.0132 & Aveng Limited & 0.8220 \\
\hline 17. MMI Holdings Limited & 20 & Woolworths Holdings Limited & 0.0129 & FirstRand Bank Limited & 0.8214 \\
\hline 18. Nedbank, Ltd. & 20 & Vantage Capital Group & 0.0127 & Discovery Limited & 0.8207 \\
\hline $\begin{array}{l}\text { 19. Anglo American Platinum } \\
\text { Limited }\end{array}$ & 19 & Incwala Resources (Pty) Ltd. & 0.0121 & $\begin{array}{l}\text { Development Bank of } \\
\text { Southern Africa, The }\end{array}$ & 0.8205 \\
\hline $\begin{array}{l}\text { 20. Barclays Africa Group } \\
\text { Limited }\end{array}$ & 19 & $\begin{array}{l}\text { Alexander Forbes Equity } \\
\text { Holdings (Proprietary) Limited }\end{array}$ & 0.0120 & Naspers Ltd. & 0.8155 \\
\hline 21. Discovery Limited & 19 & Imperial Holdings Limited & 0.0115 & Telkom SA SOC Limited & 0.8153 \\
\hline 22. FirstRand Bank Limited & 19 & Ambit Properties & 0.0115 & Angus W. B. Band & 0.8132 \\
\hline 23. Grindrod Limited & 19 & The World Bank Group & 0.0113 & Investec Bank Limited & 0.8125 \\
\hline $\begin{array}{l}\text { 24. Old Mutual Life } \\
\text { Assurance Company } \\
\text { (South Africa) }\end{array}$ & 19 & DigiCore Holdings Limited & 0.0105 & Tiger Brands Limited & 0.8124 \\
\hline 25. Telkom SA SOC Limited & 19 & Eqstra Holdings Limited & 0.0105 & MMI Holdings Limited & 0.8105 \\
\hline $\begin{array}{l}\text { 26. African Rainbow Minerals } \\
\text { Limited }\end{array}$ & 18 & Tongaat Hulett Limited & 0.0105 & Metropolitan Life Limited & 0.8082 \\
\hline $\begin{array}{l}\text { 27. CIDA Empowerment } \\
\text { Fund }\end{array}$ & 18 & Annuity Properties Limited & 0.0105 & Grindrod Limited & 0.8078 \\
\hline 28. Absa Bank Limited & 17 & Liberty Holdings Ltd. & 0.0099 & Kumba Iron Ore Ltd. & 0.8064 \\
\hline 29. ABSA GROUP LTD & 17 & $\begin{array}{l}\text { Anglo American Platinum } \\
\text { Limited }\end{array}$ & 0.0098 & Absa Bank Limited & 0.8058 \\
\hline $\begin{array}{l}\text { 30. African Rainbow Minerals } \\
\text { Gold Ltd. }\end{array}$ & 17 & Telkom SA SOC Limited & 0.0098 & ABSA GROUP LTD & 0.8057 \\
\hline 31. MTN Group Limited & 17 & Investec plc & 0.0097 & Fedsure Holdings Ltd. & 0.8045 \\
\hline 32. Naspers Ltd. & 17 & Distell Group Limited & 0.0093 & $\begin{array}{l}\text { Old Mutual Life Assurance } \\
\text { Company (South Africa) }\end{array}$ & 0.8027 \\
\hline 33. Nedbank Group Limited & 17 & $\begin{array}{l}\text { African Rainbow Minerals } \\
\text { Limited }\end{array}$ & 0.0091 & $\begin{array}{l}\text { Woolworths Holdings } \\
\text { Limited }\end{array}$ & 0.7949 \\
\hline 34. Old Mutual plc & 17 & Sun International Ltd. & 0.0087 & PPC Limited & 0.7930 \\
\hline $\begin{array}{l}\text { 35. Alexander Forbes Equity } \\
\text { Holdings (Proprietary) } \\
\text { Limited }\end{array}$ & 16 & Fedsure Holdings Ltd. & 0.0085 & Hudaco Industries Limited & 0.7929 \\
\hline $\begin{array}{l}\text { 36. Development Bank of } \\
\text { Southern Africa, The }\end{array}$ & 16 & Curro Holdings Limited & 0.0083 & Oceana Group Ltd. & 0.7923 \\
\hline $\begin{array}{l}\text { 37. FirstRand EMA Holdings } \\
\text { Limited }\end{array}$ & 16 & Old Mutual plc & 0.0081 & Nedbank, Ltd. & 0.7896 \\
\hline 38. Imperial Holdings Limited & 16 & Pioneer Food Group Ltd. & 0.0070 & $\begin{array}{l}\text { Pick n Pay Holdings } \\
\text { Limited }\end{array}$ & 0.7879 \\
\hline $\begin{array}{l}\text { 39. Kagiso Tiso Holdings } \\
\text { Proprietary Limited }\end{array}$ & 16 & Angus W. B. Band & 0.0070 & BSi Steel Limited & 0.7857 \\
\hline $\begin{array}{l}\text { 40. The Standard Bank of } \\
\text { South Africa Limited }\end{array}$ & 16 & $\begin{array}{l}\text { Nimble Group (Proprietary) } \\
\text { Limited }\end{array}$ & 0.0068 & Nedbank Group Limited & 0.7849 \\
\hline
\end{tabular}

Again, a high degree centrality means that these companies have the highest number of direct connections to directors, while a high betweenness centrality means that these companies function as linchpins in connecting the 
network around the banking industry, and closeness centrality indicates that these companies are relatively closely connected to the rest of the network. Note the companies with high betweenness centrality scores: some are in the mining industry (e.g., African Rainbow Minerals Limited and Anglo American Platinum Limited), others in the food industry (e.g., Pioneer Food Group Ltd., Woolworths Holdings Limited, and Tongaat Hulett Limited), and even the paper and tourism industries are represented (e.g., Sappi Limited and Sun International Ltd.).

All of the major South African banks, ABSA, Standard Bank, Nedbank, and FirstRand, are connected to each other, as the following graph shows:

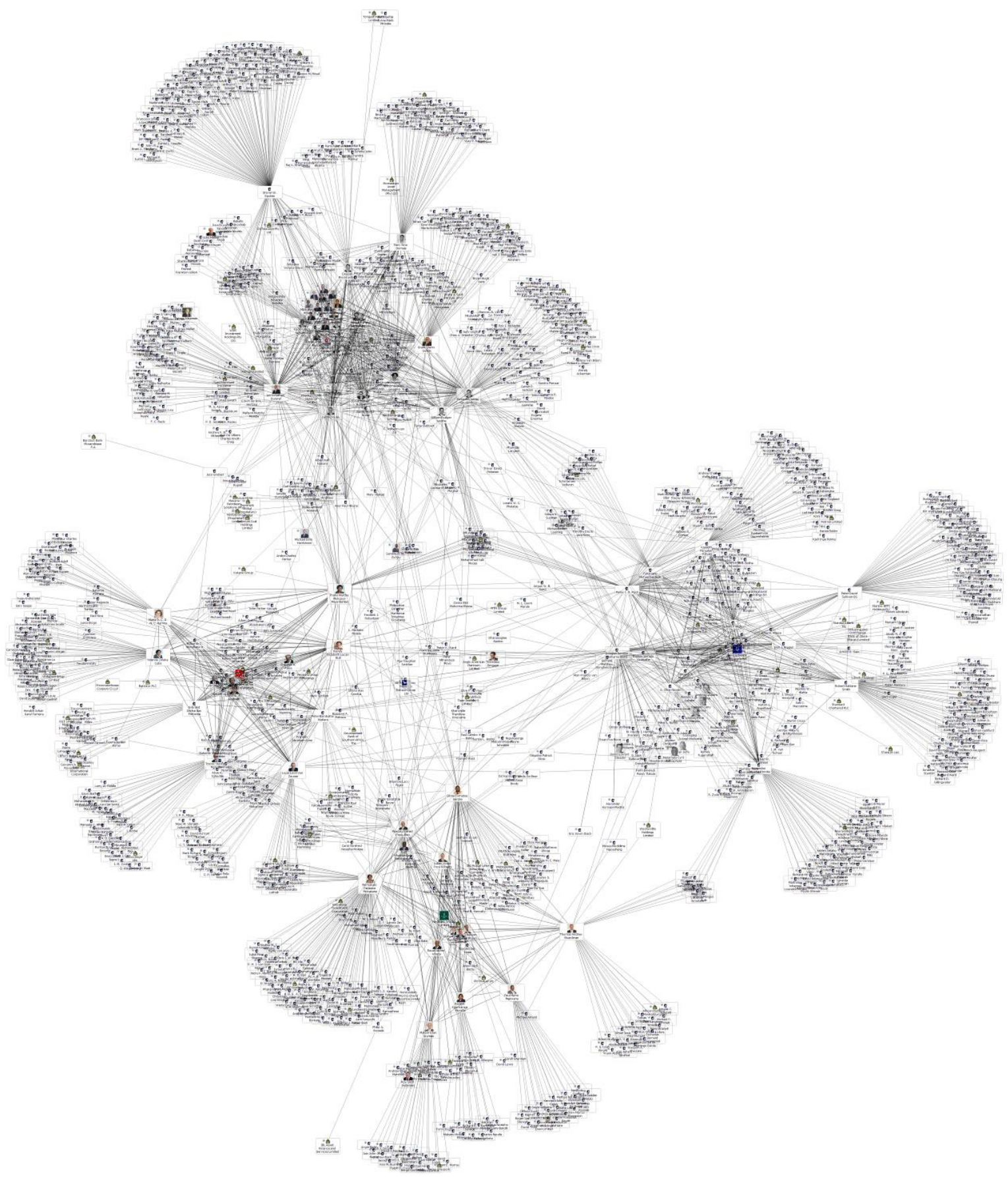

Figure 2: The Connections Between the Four Major South African Banks 
In this graph, it can be seen that although clusters form around individual banks (e.g., around Standard Bank on the right), numerous close connections exist between banks. In general, Nedbank (at the bottom) is more closely associated with Absa (left) and Standard Bank (right) than with FirstRand (at the top). In addition, other South African banks are also found on this graph, meaning that they also have close ties with the major banks: Bidvest can be seen in the middle, with close ties to particularly Absa, while Grindrod can be found at the top, with close ties to FirstRand.

The above table also shows that the South African banking industry is linked to a variety of companies in the South African economy. One such industry is private healthcare. In the following graph, the second degree connections of Mediclinic International Limited, Discovery Limited, and Life Healthcare Group Holdings Limited are represented, where it can be seen that these three companies are closely connected:

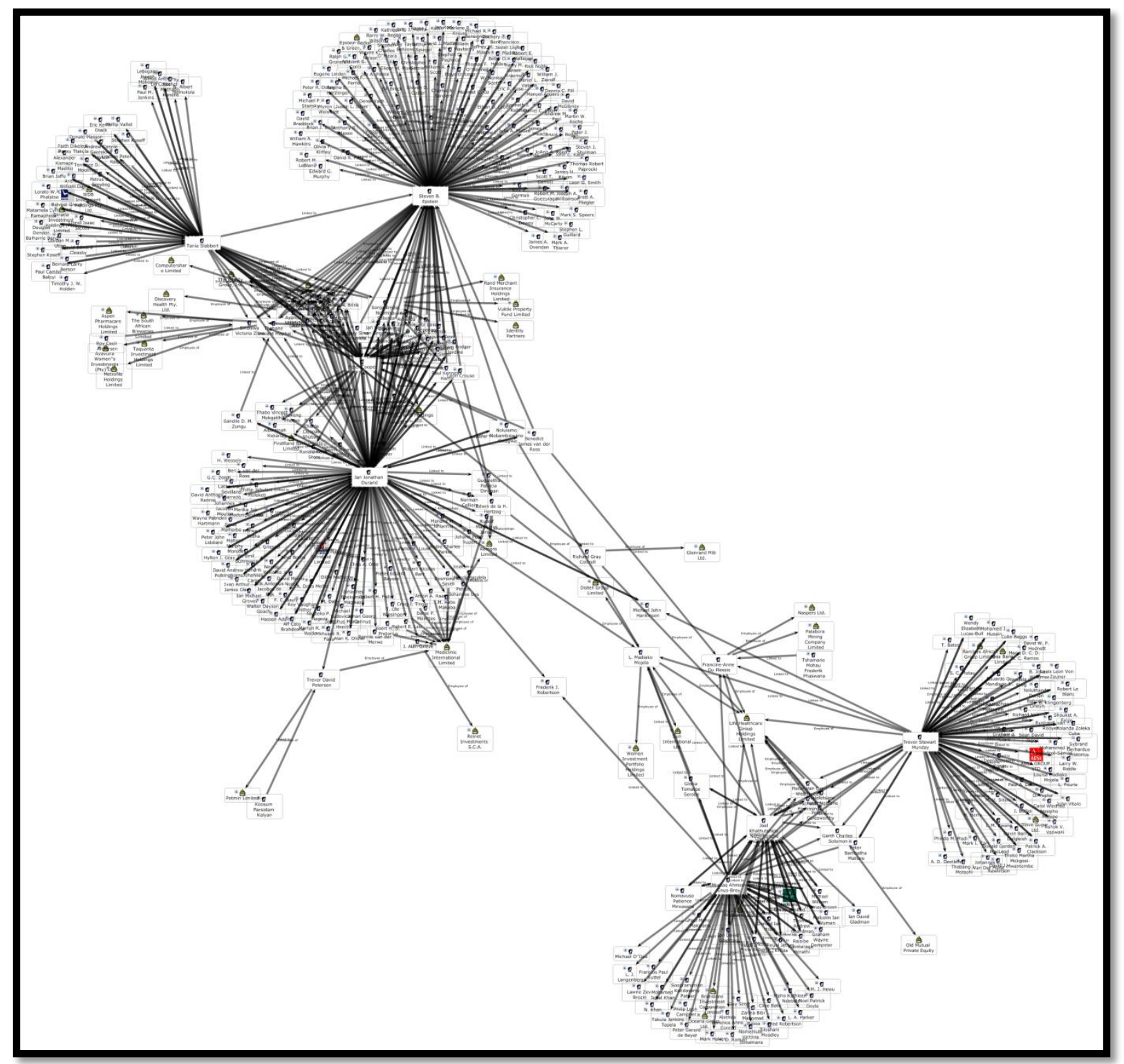

Figure 3: The Second Degree Connections of Mediclinic International Limited, Discovery Limited and Life Healthcare Group Holdings Limited 
These three companies are of course differently affiliated. Discovery is connected to the Bidvest Group Limited, Grindrod Limited, and FirstRand Limited, while Life Healthcare Group Holdings Limited is connected to ABSA Group Limited and Nedbank Group Limited, and Mediclinic International Limited is not closely affiliated to any South African bank.

The banking industry is of course also affiliated with the mining industry: Palabora Mining Company Limited, Harmony Gold Mining Company Limited, Endeavour Mining Corporation, Mmakau Mining (Pty) Ltd., TEAL Exploration \& Mining Incorporated, Sentula Mining Limited, BlackRock World Mining Trust plc, and Mvuzo Mining Ltd. are all part of this dataset (remember that the network uses data on the banking industry, not the mining industry). However, a second degree exploration of these companies' connections reveals that none of these companies are as closely affiliated with the banking industry as the healthcare industry is, and it is only when third degree connections (indicated in Table 3) are explored that connections to banks are found.

Table 3: The Third Degree Bank Affiliations of the Mining Companies ${ }^{1}$

\begin{tabular}{|l|l|}
\hline \multicolumn{1}{|c|}{ Company } & \multicolumn{1}{c|}{ South African Bank } \\
\hline Palabora Mining Company Limited & Nedbank Group Limited, ABSA Group, Standard Bank Group Limited \\
\hline Harmony Gold Mining Company Limited & $\begin{array}{l}\text { Nedbank Group Limited, ABSA Group, Standard Bank Group Limited, } \\
\text { Bidvest Group }\end{array}$ \\
\hline Endeavour Mining Corporation & ABSA Group \\
\hline Mmakau Mining (Pty) Ltd. & Capitec Bank \\
\hline Sentula Mining Limited & Grindrod Limited, FirstRand Limited, \\
\hline TEAL Exploration \& Mining Incorporated & Grindrod Limited, Standard Bank Group Limited \\
\hline BlackRock World Mining Trust plc & Investec Limited \\
\hline Mvuzo Mining Ltd & Nedbank Group Limited \\
\hline
\end{tabular}

More specifically, four companies are present in the dataset that specialise in platinum: Northam Platinum Ltd, Anglo American Platinum Limited, Impala Platinum Holdings Ltd., and Royal Bafokeng Platinum Limited. Apart from Anglo American Platinum Limited, which is linked to the banking industry in two degrees, these companies are also not affiliated with the banking industry in two degrees, but in three degrees, they are affiliated in the following way:

Table 4: The Third Degree Bank Affiliations of Platinum Mining Companies

\begin{tabular}{|l|l|}
\hline \multicolumn{1}{|c|}{ Company } & \multicolumn{1}{c|}{ South African Bank } \\
\hline Northam Platinum Ltd & ABSA Group \\
\hline Anglo American Platinum Limited & ABSA Group, Mercantile Bank Limited, Standard Bank Group Limited \\
\hline Impala Platinum Holdings Ltd. & ABSA Group, Standard Bank Group Limited, Nedbank Group Limited \\
\hline Royal Bafokeng Platinum Limited & ABSA Group, Standard Bank Group Limited \\
\hline
\end{tabular}

What can be extrapolated from the above is that although the mining industry is not as closely affiliated with the banking industry as the healthcare industry, some banks - in particular ABSA and Standard Bank - are relatively closely connected to the mining industry in South Africa. This distance between the banking industry and the mining industry, in contrast with the health care industry, warrants further exploration in another study.

The same occurs when the second degree connections of various oil companies are explored. While Aker Oilfield Services AS, Falcon Oil \& Gas Ltd., Oil and Natural Gas Cor Ltd., Forest Oil Corporation, Oil Refineries Ltd., Petroleum, Oil and Gas Corporation of South Africa (SOC) Ltd., Shell Oil Products Company LLC, and Sasol Ltd. are all part of the dataset, none of these companies have close affiliations (second degree connections) with the South African banking industry. Within three degrees, these companies are connected to the following South African banks:

\footnotetext{
${ }^{1}$ Of course there are many more mining companies; these are simply provided as an example.
} 
Table 5: The Third Degree Bank Affiliations of Oil Companies

\begin{tabular}{|l|l|}
\hline \multicolumn{1}{|c|}{ Company } & \multicolumn{1}{c|}{ South African Bank } \\
\hline Aker Oilfield Services & Standard Bank Group Limited \\
\hline Falcon Oil \& Gas Ltd. & Bidvest Group Limited \\
\hline Oil and Natural Gas CorLtd. & Standard Bank Group Limited \\
\hline Forest Oil Corporation & Bidvest Group Limited \\
\hline Oil Refineries Ltd. & Habas Investments (1960) Ltd. \\
\hline Petroleum, Oil and Gas Corporation of South Africa (SOC) Ltd. & Ubank Limited and Grindrod Limited \\
\hline Shell Oil Products Company LLC & Standard Bank Group Limited \\
\hline Sasol Ltd. & $\begin{array}{l}\text { ABSA Group Limited, Sasfin Holdings Limited, Bidvest } \\
\text { Group Limited, Standard Bank Group Limited }\end{array}$ \\
\hline
\end{tabular}

The most striking feature in the above table is that Sasol has more connections with the South African banking industry than any other company, although Sasol's long standing in the South African economy would predict that it would be the best-connected company of the above oil companies. What is surprising, however, is that Standard Bank and Bidvest dominate this industry - a feature of the South African economy that could be explored in future studies.

The only tertiary education institutions that are connected to the banking industry are the Universities of Rhodes, South Africa, Kwazulu Natal, Witwatersrand, and Cape Town. Of these universities, only one university has more than one connection: The University of Cape Town, which is linked through three directors (Paul M. G. Truyens, Mncedisi Mayekiso, and Anthony H. Miller). When second degree connections of universities are however considered, meaning not only to which directors they are linked but also to which other companies these directors are linked, Cape Town and Kwazulu Natal are linked, while Rhodes and the Witwatersrand are also connected: 


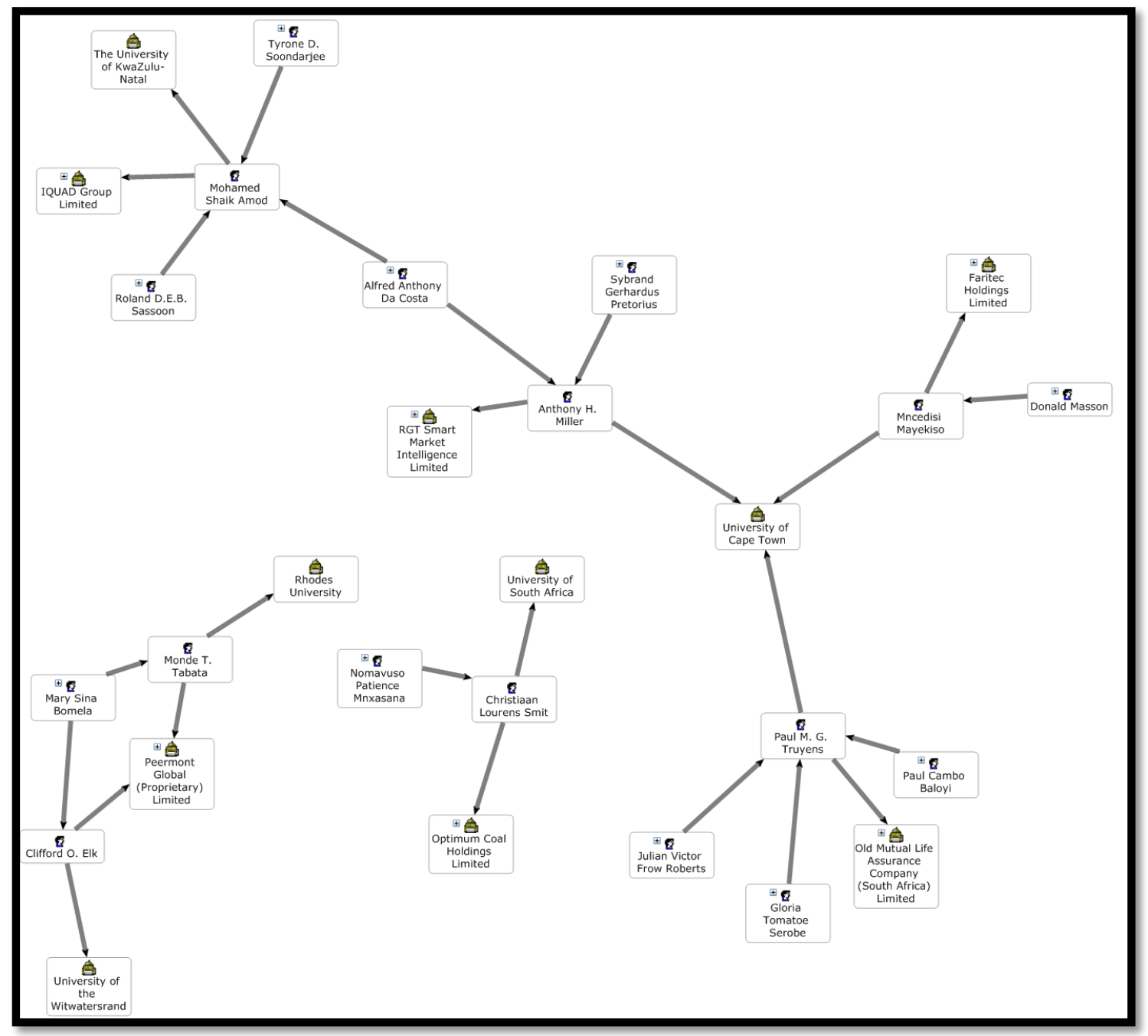

Figure 4: The Second Degree Connections of Universities

Like the mining industry, tertiary institutions are therefore not closely affiliated with the banking industry, but a more interesting question to ask would be why traditionally English universities are connected to the banking industry, and not traditionally Afrikaans universities (e.g., the University of Pretoria, Stellenbosch, North-West, or the Free State).

\section{THE CORE/PERIPHERY STRUCTURE IN THE SOUTH AFRICAN BANKING DIRECTOR NETWORK}

The distinction between core and periphery is an important concept in the application of network theory to international trade. A position at the core of the network indicates that such an entity is well connected and occupies a central role in the network, while those entities positioned at the periphery play a lesser role in their industry and are also less connected. To position entities within the network, force-directed algorithms are employed, which see entities within a network as similar to physical entities, with their connections acting in a similar way to physical forces of attraction and repulsion (Merico, Gfeller, \& Bader, 2009, p. 922; Fruchterman \& Reingold, 1991 ;Suderman \& Hallett, 2007, p. 2654). Kwapień and Drożdż (2012, p. 208) for instance provide the following graph constructed for the stock exchange of 1000 American companies traded on NYSE or NASDAQ: 


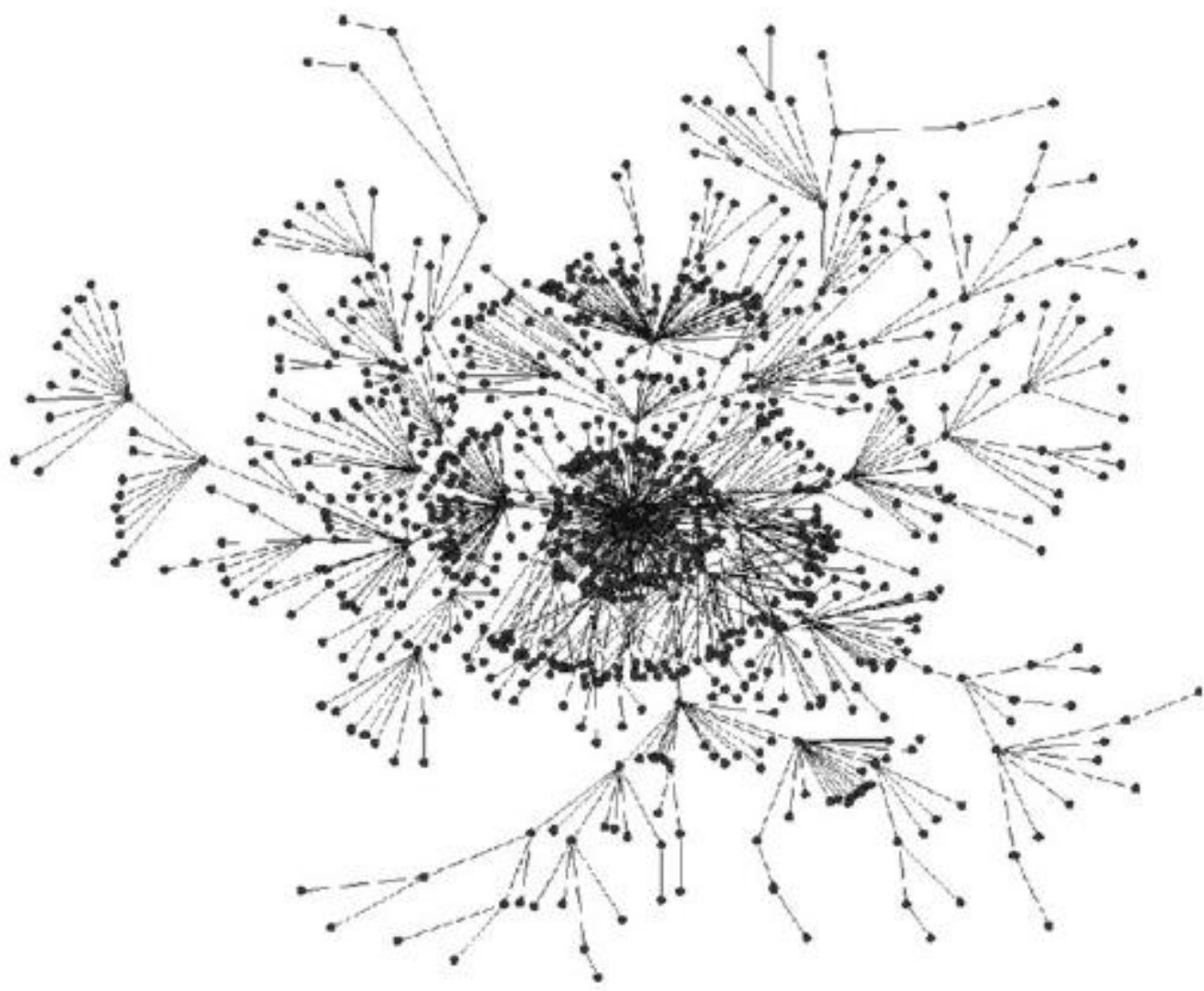

Figure 5: A Network of American Companies Traded on NYSE and NASDAQ

Here it can be seen how some companies concentrate connections around them and are subsequently positioned at the core, while less well-connected companies are positioned at the periphery. The companies at the very periphery of the network for instance only have one connection, and notably, that one connection is also to a company that has few other structurally important connections. In contrast, entities at the core are linked to other well-connected entities through a multitude of ties - a visual manifestation of degree correlation as mentioned above.

In the banking director network under consideration here, a similar core/periphery structure can be observed. Of course, both Habas Investments (1960) Ltd. and Albaraka Turk Katilim Bankas are generally peripheral, as they do not have ties (in terms of directors) to the rest of the network. Since the network under consideration here is concerned with South African banks, all the other South African banks are found in the core of this network. The other companies that share the core, however, are more interesting: these are the companies that are positioned closest to the South African banking industry. The following graph shows where 20 of these companies can be found (in no particular order): 
Table 6: Other Companies That Share the Core

\begin{tabular}{|ll|}
\hline & Company \\
\hline 1. & Sun International Limited \\
\hline 2. & Illovo Sugar Limited \\
\hline 3. & Mr Price Limited \\
\hline 4. & Anglo American PLC \\
\hline 5. & BSi Steel Limited \\
\hline 6. & Woolworths Holdings Limited \\
\hline 7. & Life Healthcare Group Holdings Limited \\
\hline 8. & Naspers Limited \\
\hline 9. & Sasol Limited \\
\hline 10. & Vodafone Group Public Limited Company \\
\hline 11. & PAREXEL International \\
\hline 12. & Pick 'n Pay \\
\hline 13. & Lewis Group \\
\hline 14. & Spar Group Limited \\
\hline 15. & Clicks Group Limited \\
\hline 16. & De Beers Consolidated Mines Limited \\
\hline 17. & Tiger Oats Limited \\
\hline 18. & Cashbuild \\
\hline 19. & Harmony Gold Mining Company Limited \\
\hline 20. & Nampak Limited \\
\hline
\end{tabular}

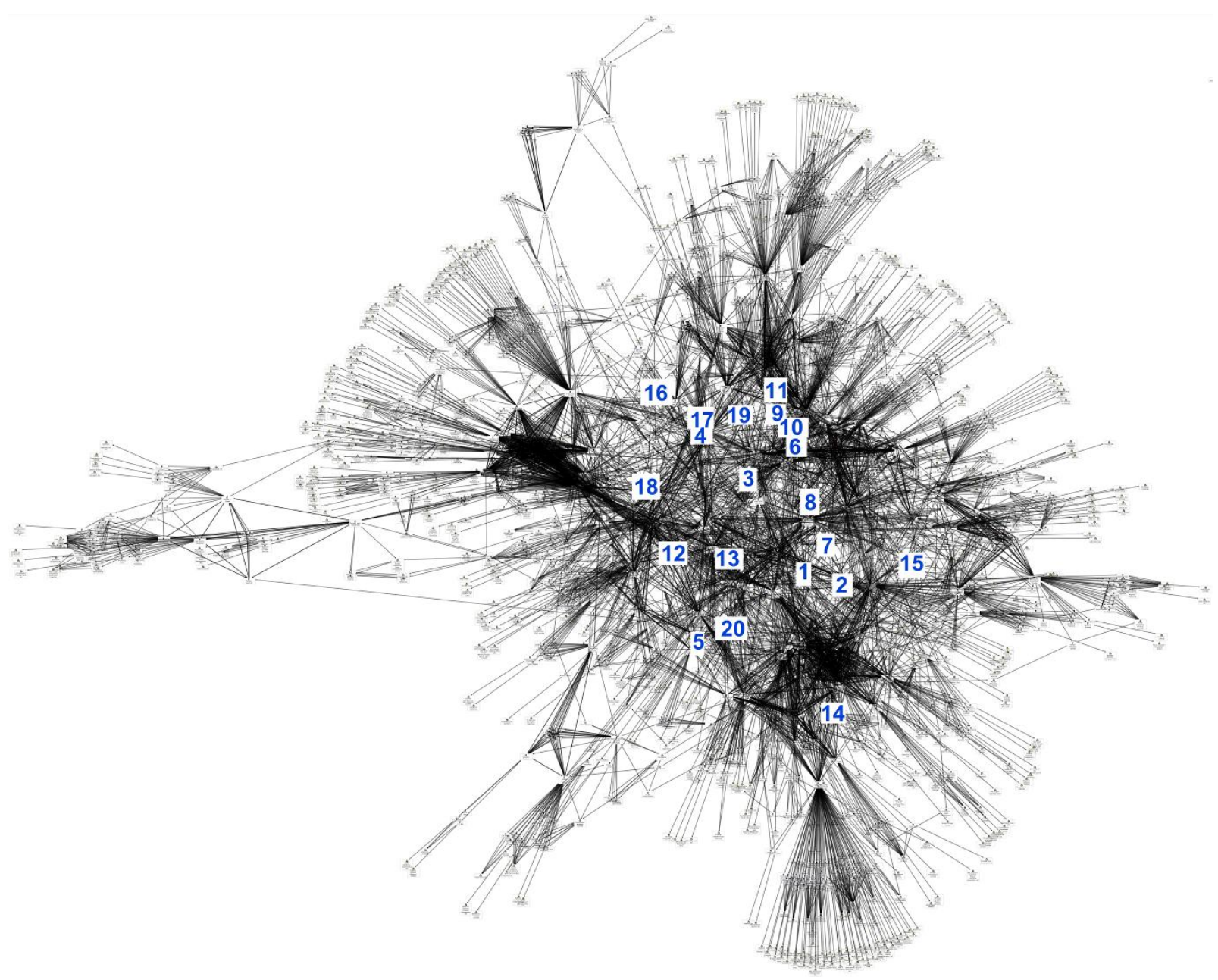

Figure 6: Central Companies in the Bank Industry Director Network 
Here it can be seen how the force-directed algorithms has positioned the above companies - all at the core of the South African banking director network. Future studies could explore these companies' connections in more detail: which connections contributed to these companies' positions? Are there specific sectors of the South African economy that are particularly well represented at the core? Which companies (and by implication, financial sectors) are on the periphery, and why?

\section{CONCLUSION}

This article has shown how densely connected the banking industry director network is in South Africa. More specifically, it was shown which directors and companies have the highest degree-, betweenness-, and closeness centrality scores, meaning which companies and directors are the most active, play the role of linchpins most often, and are closest to the rest of the network specifically. Because this was an exploratory study using a method that is unfamiliar in South Africa, the article also generated many questions: Why is the healthcare industry more closely connected to the banking industry than the mining industry? Which other financial sectors and companies are at the core of this network, which ones are at the periphery, and why? In addition, this study provided only a single glimpse of a dynamically evolving network: How did it change over time? How did it change since 1994 ?

Most importantly, this article has shown that the theory of complex networks has a lot to offer South African economics, as it has in other parts of the world, and in other disciplines as well. A more detailed effort is needed to map the South African economy - in terms of director networks but also trade networks in general - in order to come to a better understanding of how the South African economy functions as a complex system.

\section{AUTHOR INFORMATION}

Burgert A. Senekal has been affiliated with the University of the Free State (UFS) since 2008, and is currently a researcher at the Centre for Language Facilitation and Empowerment. He obtained two Master's degrees in literature: one in Afrikaans (2005), and one in English (2008). He is currently completing his $\mathrm{PhD}$ in Afrikaans at the UFS. After his initial publications within the framework of alienation theory, his recent research interests include systems theory, network theory, and information technology, especially where information technology can be harnessed within the framework of network theory to analyze complex social systems. Burgert A. Senekal, Unit for Language Facilitation and Empowerment, University of the Free State, South Africa. E-mail: senekalba@ufs.ac.za

Karlien Stemmet was appointed as a lecturer at the Department of Economics and Money and Banking at the University of the Free State (UFS) in 2002. She obtained her Master's degree in Economics (cum laude) in 2001 and is currently completing her $\mathrm{PhD}$ in Economics and Competition Law. Her interest includes the South African banking industry, the economics of competition law and complex social systems. Karlien Kitching, Department of Economics, University of the Free State, PO Box 339, Department of Economics, Faculty Economic and Management Sciences, Flippie Groenewoud Building, Bloemfontein, Free State, South Africa, 9300. E-mail: kitchk@ufs.ac.za (Corresponding author)

\section{REFERENCES}

1. Alexander, M. (2003). Boardroom networks among Australian company directors, 1976 and 1996 The impact of investor capitalism. Journal of Sociology, 39(3), 231-251.

2. Amaral, L. A. N., \& Ottino, J. M. (2004). Complex networks. Augmenting the framework for the study of complex systems. European Physical Journal, 38, 147-162.

3. Barabási, A.-L. (2009). Scale-free networks: A decade and beyond. Science, 325(5939), 412-413.

4. Barabási, A.-L., \& Albert, R. (1999). Emergence of scaling in random networks. Science, 286, 509-511.

5. Barnes, R. C., \& Ritter, E. R. (2001). Networks of corporate interlocking: 1962-1995. Critical Sociology, 27(2), 192-220.

6. Brandes, U., Freeman, L. C., \& Wagner, D. (2013).'Social networks In R. Tamassia (ed.) Tamassia, Roberto, CRC Press. 
7. Buchanan, M. (2003). Nexus: Small worlds and the groundbreaking science of networks, New York: W.W. Norton \& Co.

8. Butts, C. T. (2008). Social network analysis: A methodological introduction. Asian Journal of Social Psychology, 11, 13-41.

9. Clauset, A., Shalizi, C. R., \& Newman, M. E. (2009). Power-law distributions in empirical data. SIAM Review, 51(4), 661-703.

10. Comet, C., \& Pizarro, N. (2011). The cohesion of intercorporate networks in France. Procedia-Social and Behavioral Sciences, 10, 52-61.

11. Conyon, M. J., \& Muldoon, M. R. (2006). The small world of corporate boards. Journal of Business Finance \& Accounting, 33(9/10), 1321-1343.

12. Davis, G. F., \& Mizruchi, M. S. (1999). The money center cannot hold: Commercial banks in the US system of corporate governance. Administrative Science Quarterly, 44(2), 215-239.

13. Davis, G. F., Yoo, M., \& Baker, W. E. (2003). The small world of the American corporate elite, 19822001. Strategic organization, 1(3), 301-326.

14. De Benedictis, L., \& Tajoli, L. (2008). The World Trade Network. University of Macerata.

15. Donges, J. F., Zou, Y., Marwan, N., \& Kurths, J. (2009). Complex networks in climate dynamics: Comparing linear and nonlinear network construction methods. The European Physical Journal Special Topics, 174, 157-179.

16. Dos Santos, D. A., Cuezzo, M. G., Reynaga, M. C., \& Dominguez, E. (2012). Towards a dynamic analysis of weighted networks in biogeography. Systematic Biology, 61(2), 240-252.

17. Flandreau, M., \& Jobst, C. (2005). The ties that divide: A network analysis of the international monetary system 1890-1910. The Journal of Economic History, 65(4), 977-1007.

18. Flandreau, M., \& Jobst, C. (2009). The empirics of international currencies: Network externalities, history and persistence. The Economic Journal, 119(537), 643-664.

19. Freeman, L. C. (1979). Centrality in social networks conceptual clarification. Social Networks, 1(3), 215239.

20. Fricke, D., Finger, K., \& Lux, T. (2013). On assortative and disassortative mixing scale-free networks: The case of interbank credit networks. (Kiel Working Paper no. 1830). Kiel Institute for the World Economy.

21. Fruchterman, T. M. J., \& Reingold, E. M. (1991). Graph drawing by force-directed placement. Software: Practice and Experience, 21(11), 1129-1164.

22. Hafner-Burton, E., Kahler, M., \& Montgomery, A. (2009). Network analysis for international relations. International Organization, 63(3), 559-592.

23. Haldane, A. G. (2009). Rethinking the financial network. Speech delivered at the Financial Student Association, 1-41.

24. Heemskerk, E. M. (2013). The rise of the European corporate elite: evidence from the network of interlocking directorates in 2005 and 2010. Economy and Society, 42(1), 74-101.

25. Jackson, M. (2007). The economics of social networks. In R. Blundell, W. Newey, \& T. Persson (ed.), Proceedings of the 9th World Congress of the Econometric Society, Cambridge: Cambridge University Press.

26. Koskinen, J., \& Edling, C. (2012). Modelling the evolution of a bipartite network-Peer referral in interlocking directorates. Social Networks, 34(3), 309-322.

27. Kwapień, J., \& Drożdż, S. (2012). Physical approach to complex systems. Physics Reports, 515(3), 115226.

28. Levine, J. H. (1977). The network of corporate interlocks in the United States: An overview. Paper presented at the American Sociological Association Annual Meeting.

29. Luke, D. A., \& Stamatakis, K. A. (2012). Systems science methods in public health: Dynamics, networks, and agents. Annual Review of Public Health, 33, 357-376.

30. Mahdi, K., Almajid, A., Safar, M., Riquelme, H., \& Torabi, S. (2012). Social network analysis of Kuwait publicly-held corporations. Procedia Computer Science, 10, 272-281.

31. Merico, D., Gfeller, D., \& Bader, G. D. (2009). How to visually interpret biological data using networks. Nature biotechnology, 27(10), 921-924.

32. Mintz, B., \& Schwartz, M. (1985). The power structure of american business. Chicago, IL: University of Chicago Press. 
33. Mizruchi, M. S. (1982). The american corporate network: 1904-1974, Beverly Hills, CA: Sage Publications.

34. Nemeth, R., \& Smith, D. A. (1985). International trade and world-system structure: A multiple network analysis. Review, 8, 517-560.

35. Newman, M. E. J. (2001). The structure of scientific collaboration networks. Proceedings of the National Academy of Sciences, 98(2), 404-409.

36. Newman, M. E. J. (2003). The structure and function of complex networks. SIAM Review, 45(2), 167-256.

37. Newman, M. E. J. (2005). Power laws, Pareto distributions and Zipf's law. Contemporary physics, 46(5), 323-351.

38. Nicholson, G. J., Alexander, M., \& Kiel, G. C. (2004). Defining the social capital of the board of directors: An exploratory study. Journal of Australian New Zealand Academy of Management, 10(1), 54-72.

39. Onel, S., Zeid, A., \& Kamarthi, S. (2011). The structure and analysis of nanotechnology co-author and citation networks. Scientometrics, 89(1), 119-138.

40. Prell, C. (2012). Social network analysis. History, theory and methodology, London: Sage.

41. Robins, G., \& Alexander, M. (2004). Small worlds among interlocking directors: Network structure and distance in bipartite graphs. Computational and Mathematical Organization Theory, 10, 69-94.

42. Serrat, O. (2010). Social network analysis. Washington, DC: Asian Development Bank.

43. Smith, D. A., \& White, D. R. (1992). Structure and dynamics of the global economy: Network analysis of international trade1965-1980. Social Forces, 70(4), 857-893.

44. Snyder, D., \& Kick, E. (1979). Structural position in the world system and economic growth: A multiple network analysis of transnational interactions. American Journal of Sociology, 84, 1096-112.

45. South African Reserve Bank (2012). Bank Supervision Department Annual Report 2012.

46. Steiber, S. (1979). The world system and world trade: An empirical explanation of conceptual conflicts. The Sociological Quarterly, 20, 23-36.

47. Strogatz, S. (2004)[2003]. Sync. The emerging science of spontaneous order, London: Penguin.

48. Suderman, M., \& Hallett, M. (2007). Tools for visually exploring biological networks. Bioinformatics, 23(20), 2651-2659.

49. Useem, M. (1984). The inner circle. New York: Oxford University Press.

50. Watts, D. J. (2004). The 'new' science of networks. Annual review of sociology, 30, 243-270.

51. Watts, D. J. (2004)[2003]. Six degrees. The science of a connected age. London: Vintage.

52. Watts, D. J., \& Strogatz, S. H. (1998). Collective dynamics of 'small-world' networks. Nature, 393(6684), 409-410.

53. Zhu, B., Watts, S., \& Chen, H. (2010). Visualizing social network concepts. Decision Support Systems, 49(2), 151-161. 